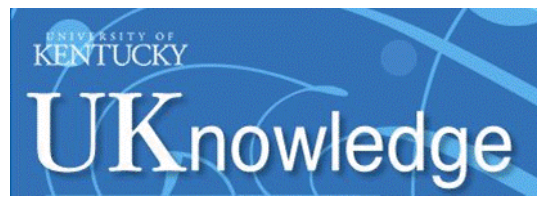

University of Kentucky

UKnowledge

\title{
Do College Rankings Matter? Examining the Influence of "America's Best Black Colleges" on HBCU Undergraduate Admissions
}

Willis A. Jones

University of Kentucky, willis.a.jones@uky.edu

Follow this and additional works at: https://uknowledge.uky.edu/epe_facpub

Part of the Educational Assessment, Evaluation, and Research Commons, and the Higher Education Commons

Right click to open a feedback form in a new tab to let us know how this document benefits you.

\section{Repository Citation}

Jones, Willis A., "Do College Rankings Matter? Examining the Influence of "America's Best Black Colleges" on HBCU Undergraduate Admissions" (2016). Educational Policy Studies and Evaluation Faculty Publications. 5.

https://uknowledge.uky.edu/epe_facpub/5

This Article is brought to you for free and open access by the Educational Policy Studies and Evaluation at UKnowledge. It has been accepted for inclusion in Educational Policy Studies and Evaluation Faculty Publications by an authorized administrator of UKnowledge. For more information, please contact UKnowledge@lsv.uky.edu. 
Do College Rankings Matter? Examining the Influence of "America's Best Black Colleges" on HBCU Undergraduate Admissions

\author{
Digital Object Identifier (DOI) \\ https://doi.org/10.1086/684550 \\ Notes/Citation Information \\ Published in American Journal of Education, v. 122, no. 2, p. 247-265. \\ (C) 2016 by The University of Chicago. All rights reserved.
}

The copyright holder has granted the permission for posting the article here. 


\title{
Do College Rankings Matter? Examining the Influence of "America's Best Black Colleges" on HBCU Undergraduate Admissions
}

\author{
WILLIS A. JONES \\ University of Kentucky
}

College rankings have become a ubiquitous part of American higher education. As the popularity of rankings has increased, so have the number of research studies attempting to better understand the impact rankings have on college/ university admissions outcomes. In the past, these studies have focused almost exclusively on elite national universities and liberal arts colleges. This study broadens research in this area by examining how the introduction of U.S. Newes and World Report's "America's Best Black Colleges" section influenced undergraduate admissions among historically black colleges and universities (HBCUs). The findings suggest that college rankings have little correlation with admissions outcomes at HBCUs.

Since its inception in 1983, U.S. News and World Report's (USNWR) annual rankings of higher education institutions titled "America's Best Colleges" has grown into arguably the nation's most popular college ranking publication. The release of the new rankings each fall is often front-page news among local and national media outlets. Though many administrators claim to detest the rankings, colleges and universities regularly tout their ranking in news releases, on institutional websites, and in alumni publications (Monks and Ehrenberg 1999). The popularity of the rankings is also evident in the annual sales and use of the publication. "America's Best Colleges" and its graduate school equivalent, "America's Best Graduate Schools," are among the best-selling issues of USNWR each year (U.S. Newes and World Report 2008). In 2007, USNWR publisher Kerry Dyer reported that within 72 hours of the release of the college rankings, the

Electronically published December 16, 2015

American Journal of Education 122 (February 2016)

(C) 2016 by The University of Chicago. All rights reserved.

0195-6744/2016/12202-0003\$10.00

FEBRUARY 2016 


\section{Do College Rankings Matter?}

USNWR website receives approximately 10 million page views. Typically, the website receives approximately 500,000 page views a month (Freedman 2007).

The popularity of the USNWR rankings has been the impetus for increased empirical analyses of the impact of these rankings on various aspects of higher education. Much of this research has focused on how rankings impact undergraduate admissions. Studies by Bowman and Bastedo (2009), Griffith and Rask (2007), Luca and Smith (2013), and Monks and Ehrenberg (1999) have attempted to examine the impact of the USNWR rankings on an institution's ability to attract undergraduate students. The present study looks to supplement this growing body of research by exploring how the introduction of the USNWR “America's Best Black Colleges" section of the larger USNWR rankings influenced undergraduate admissions among historically black colleges and universities (HBCUs).

The following section reviews past scholarship, which has explored the impact of college rankings on the college and university admissions process. This review highlights the lack of focus on HBCUs. This is followed by a conceptual framework for understanding the impact of rankings on student college choice and institutional admissions. The article concludes with details of the research design used, the study findings, and the implications of these findings for scholars and practitioners.

\section{The Impact of Rankings on Higher Education Admissions:}

\section{A Literature Review}

Research on the impact of college rankings on undergraduate admissions has primarily taken two forms. The first uses student survey data to explore the importance of institutional rankings in the college choice process. The limited evidence from this strand of research suggests that published college rankings do not play a significant role in students' college choices. McDonough et al. (1998) found that $59.9 \%$ of the more than 220,000 undergraduates surveyed in the 1995 Cooperative Institutional Research Program (CIRP) Freshman Survey said college rankings from news sources and magazines were not at all important in their college decisions. In an update of these findings using data from 2006, the CIRP found that $48.4 \%$ of freshmen reported that college rankings

WILLIS A. JONES is an assistant professor of higher education at the University of Kentucky. Dr. Jones's primary area of research is related to the study of intercollegiate athletics. He has also published on the topics of historically black colleges and universities, college rankings, college student diversity, student retention, and faculty governance. 
in national magazines were not important in their decisions to enroll in colleges or universities (Higher Education Research Institute 2007). The marketing firm Lipman Hearne (2009) surveyed 1,264 high-achieving high school seniors in 2009 and found that only $14 \%$ said college rankings were very influential in their college choice decisions.

A second strand of research in this area looks at how changes in a college's or university's ranking impact applications to and enrollment in that institution. These findings somewhat contradict the conclusions of the aforementioned student survey research. Monks and Ehrenberg (1999) examined institutional data from 1988 to 1998 from 30 highly ranked private colleges and universities in an effort to determine how enrollment outcomes were influenced by changes in an institution's USNWR ranking. The findings showed a small but statistically significant correlation between rankings and admissions outcomes. Specifically, a one-unit improvement in an institution's overall rankings was correlated with a $0.399 \%$ decrease in an institutional acceptance rate, a $0.171 \%$ increase in admissions yield, and a 2.777 point increase in the average SAT score of an institution's incoming freshman class. None of the 30 schools used in this analysis were HBCUs.

Meredith (2004) also looked at the correlation between USNWR rankings and admissions outcomes. He used a sample of 233 national research universities and examined data from 1990 to 1999 . His results were similar to those of Monks and Ehrenberg (1999). An improvement in an institution's ranking from the top 50 to the top 25 was correlated with a lower acceptance rate and a more academically accomplished incoming freshman class. An institution's moving from a ranking in tier 3 or 4 in USNWR to a ranking among the top 25 institutions was also associated with lower acceptance rates and more top students in its freshman class. Meredith does not indicate whether any of the institutions used in this study were HBCUs.

Griffith and Rask (2007) also found that institutional enrollment benefits from a positive change in a school's USNWR ranking. Using survey data from high school seniors who had been admitted to Colgate University over several years, the authors found that applicants were more likely to attend a school with a higher USNWR ranking, even if the ranking of a school was only slightly higher than that of another institution. The study also found that applicants receiving need-based financial aid were less responsive to the rankings than students who did not receive financial aid. Among racial minority applicants in their dataset, Griffith and Rask found no correlation between an institution's ranking and the likelihood of student enrollment.

Bowman and Bastedo (2009) looked at how appearing on the front page of the print edition of the USNWR rankings publication impacted five measures of institutional admissions success: freshman SAT scores, the percentage of freshmen in the top $10 \%$ of their high school classes, acceptance rates, the

FEBRUARY 2016 


\section{Do College Rankings Matter?}

number of applications received, and admission yield rates. Using data from 1997 to 2004, the authors found that appearance among the top 50 national universities or among the top 50 liberal arts colleges in the USNWR rankings had a significant impact on various admissions indicators. Specifically, moving from outside the top 50 (i.e., not appearing on the front page of the USNWR rankings) to inside the top 50 (i.e., appearing on the front page of the rankings) was correlated with a decrease in institutional acceptance rate, an increase in the number of incoming freshmen who graduated in the top $10 \%$ of their high school classes, and a nearly $4 \%$ increase in the overall number of applications received the following academic year. These findings were robust for both national universities and liberal arts colleges. As with the previous studies, none of the institutions in Bowman and Bastedo's study were HBCUs.

Most recently, Luca and Smith (2013) looked to explore how rankings and the salience of rankings (defined as the simplicity of knowing a school's ranking) correlated with freshman applications, acceptance rates, yield, and student quality. Data came from schools that appeared in the USNWR top 25 or top 50 from 1990 to 2000. Ordinary least squares estimates revealed that when schools improved their rankings, applications increased and institutional acceptance rates decreased. Yield and student quality were not significantly correlated with rankings. Luca and Smith also found that the positive relationship between rankings improvement and freshman applications was especially strong when institutional rankings were more salient.

These findings reveal that the higher education community has somewhat mixed evidence for the impact of the USNWR rankings on institutional admissions. When students are asked what role rankings have on their decisions to attend a particular college or university, they indicate that the rankings do not play a significant role. Institutional level analyses, however, suggest that college or university admissions outcomes are correlated with the USNWR rankings. Specifically, having a better ranking has been found to increase the number of admissions applications an institution receives, to reduce an institution's acceptance rate, and to increase the academic quality of incoming students.

However, continued research on the relationship between the USNWR rankings and institutional admissions is needed to address an important and understudied subset of institutions: HBCUs, which were included in none of the aforementioned analyses. HBCUs, defined by the US Department of Education as institutions of higher education established before 1964 with the principal mission of the education of black Americans (White House Initiative on Historically Black Colleges and Universities, n.d.), have a well-documented history of educational excellence despite incredible obstacles. From the end of the Civil War through the period of de jure racial segregation, HBCUs were often the only sources of postsecondary education for African Americans. Despite strong opposition from southern conservatives who saw higher education 
for African Americans as a threat to white supremacy (Allen and Jewell 2002), HBCUs during this time were able to help increase literacy and educational attainment among blacks, to preserve and perpetuate black culture, and to educate a generation of black leaders who would be the pillars of the civil rights movement (Allen and Jewell 2002; Ashley et al. 2004; Lovett 2011).

Following the Supreme Court's decision in Brown v. Board of Education (1954), African Americans slowly began enrolling in previously segregated predominately white institutions (PWIs). Allen and Jewell (2002) note that whereas the overwhelming majority of African American college students were enrolled at HBCUs in 1950, by 1975 three-quarters of all African American students attended PWIs. Today there are 105 HBCUs operating in the United States. These institutions have a great deal of variety, including schools that are "public and private, religious and non-sectarian, two-year and four-year, selective and open, urban and rural" (Gasman 2013, 5). In 2011, HBCUs enrolled nearly 350,000 undergraduate students (Gasman 2013).

Given their status within higher education, their interest in the USNWR rankings, and the type of students they typically enroll, HBCUs are important institutions to study to better understand the relationship between admissions outcomes and institutional rankings. HBCUs enroll $11 \%$ of African American college students (Gasman 2013), yet they produce approximately $31 \%$ of biological science, $31 \%$ of mathematics, and $42 \%$ of agricultural science undergraduate degrees earned by African Americans (Clay 2013). According to the National Science Foundation, one-third of all African American science and engineering doctorate recipients completed their undergraduate education at an HBCU (Lee and Keys 2013).

HBCUs in recent years have also become increasingly vocal in their concerns about the USNWR rankings. Many in the HBCU community believe the rankings are inherently biased against black colleges (Kamara 2007a). The methodology used by USNWR privileges institutional characteristics such as student selectivity, graduation rates, and financial resources. These are measures in which HBCUs have traditionally underperformed in comparison to PWIs (Gasman 2013; Lee and Keys 2013). As a result, HBCUs have consistently placed low in the USNWR rankings. These low rankings, critics argue, discourage students from attending HBCUs (Kamara 2007a, 2007b). Whether HBCUs are adversely affected by their standings in the USNWR rankings, however, has not been empirically studied.

Questions regarding the impact of institutional rankings on HBCU admissions outcomes become increasingly interesting once one considers the type of students HBCUs typically enroll. In their study of student use of the magazine rankings, McDonough et al. (1998) found several patterns that would suggest that HBCUs would not be affected by the USNWR rankings as other institutions of higher education were. They found that students who place the most

FEBRUARY 2016 


\section{Do College Rankings Matter?}

importance on national rankings were most likely to be Asian American, from college-educated families, from higher income families, and academically high achieving students. The student population at HBCUs is often very different. HBCUs enroll a high number of first-generation students from low-income backgrounds. HBCUs also enroll many academically underprepared students who may not have had the opportunity to pursue postsecondary education without black colleges (Lee and Keys 2013). Based on this information, one may expect that students attending HBCUs place less emphasis on rankings than students attending other types of postsecondary institutions. As a result, HBCUs may not be significantly affected by their standings in national rankings.

To summarize, a number of empirical studies in recent years have tested whether college and university admissions outcomes are correlated with the USNWR rankings. The focus of this previous research has been almost exclusively on top 50 national universities and liberal arts colleges. Therefore, very little is known about the correlation between freshman admissions and rankings among institutions of higher education outside the top 50. One subset of institutions outside the top 50 that could help the higher education community develop a more complete picture of the rankings-admissions relationship is HBCUs because of their unique student population and consternation regarding rankings.

\section{Research Question}

This study used the introduction of the "America's Best Black Colleges" section of the USNWR rankings publication to examine the following research question:

Controlling for other indicators of university quality, did changes in college rankings within USNWR's "America's Best Black Colleges" section correlate with changes in institutional admissions indicators the following academic year?

An Overview of the USNWR “America's Best Black Colleges" Rankings

In October 2007, USNWR launched a new rankings series titled "America's Best Black Colleges." The inspiration for this new rankings section, according to USNWR assistant managing editor Kenneth Terrell, was to show the relevancy of HBCUs and to make them more visible to the readers of the USNWR 
rankings (Kamara 2007b). The black-college rankings include only 4-year HBCUs recognized by the US Department of Education and use methodology similar to that used in the larger USNWR rankings (schools are ranked based on their graduation rates, selectivity, financial resources, etc.). The major difference between the methodologies used in the black-college rankings and the larger USNWR rankings is that academic peer reputation scores of HBCUs are based on a survey of only HBCU presidents, provosts, and admissions deans.

After assigning each HBCU an overall score based on the aforementioned institutional performance measures, USNWR places them into tiers. HBCUs with the highest overall scores are placed in the first tier and ranked numerically. HBCUs with lower scores are placed in the second tier and listed alphabetically. In the 2007 black-college rankings, 37 institutions were rated as first tier black colleges, and 33 schools were rated as second tier black colleges. USNWR did not rank 11 HBCUs primarily because insufficient institutional performance data were available for them. "America's Best Black Colleges" has been published each year since 2007 .

Reaction to the USNWR HBCU rankings has been mixed. Some HBCU presidents and administrators feel they are little more than a disingenuous attempt to sell magazines. Walter Kimbrough, president of Dillard University, said, "[USNWR] did not take the time to study HBCUs, to develop the metrics in terms of creating a formula or consult scholars that study HBCUs" (Kamara 2007b, para. 11). Gasman (2011) noted that the HBCU rankings privilege highresource $\mathrm{HBCUs}$ and $\mathrm{HBCUs}$ with historically excellent reputations. She also noted that the HBCU rankings may be methodologically flawed because numerous institutions failed to complete the USNWR survey of institutional characteristics. Others in the HBCU community, however, believe the HBCU rankings increase the profile of black colleges. Michael Lomax, president of the United Negro College Fund, said, "I don't know if I would call this [the HBCU rankings] an accomplishment but it lends a new lens [to HBCUs]. . . These rankings are an opportunity for students and their families to gather information about where and what college to attend" (Kamara 2007b, para. 16). The validity of the USNWR methodology for ranking HBCUs remains a widely debated topic.

It is important to note that USNWR is not the only rankings outlet to include HBCUs. Forbes and the Princeton Revier, for example, each publish college rankings that include HBCUs. Diverse magazine and the Online College Database publish HBCU-specific college rankings. Recently, Washington Monthly published its ranking of "America's Worst Colleges." This ranking included a number of HBCUs (Gasman 2014). However, no other rankings service receives the attention of the USNWR rankings. The mid-September release of the USNWR rankings in 2013 drew 2.6 million unique visitors and 18.9 million 


\section{Do College Rankings Matter?}

page views to the USNWR rankings website in a single day (U.S. Neres and World Report 2014). Given this popularity, it is likely that the USNWR rankings have the greatest potential impact on student enrollment decisions when compared to other rankings services.

\section{Rankings and College Choice: A Conceptual Framework}

A variety of methods, assumptions, and theoretical perspectives have been employed to study student college choice (Pitre 2006). Conceptual frameworks for better understanding the college choice process have been proposed by D. Chapman (1981), R. Chapman (1986), and Jackson (1982). Arguably, the most popular student college choice model among higher education scholars is that proposed by Hossler and Gallagher in 1987, which proposes a three-stage process of student college decision making. In stage 1, labeled the predisposition stage, students determine whether they will attempt to pursue a college education following high school. The focus here is not on the intention to go to a particular college but on the decision to pursue postsecondary education.

Stage 2 of the Hossler and Gallagher model is labeled the search stage. Here, students who have made the decision to go to college start the process of gathering more information about various colleges and universities. This information is used to generate a short list of institutions that a student will seriously consider applying to. Stage 3 is the choice stage. During this stage, a student evaluates his or her short list of preferred institutions in an attempt to choose which college or university to attend.

College rankings can potentially influence each of the final two stages of the Hossler and Gallagher model and, in turn, admissions outcomes at postsecondary institutions. During the search stage, students gather information about colleges and universities from a variety of sources ranging from close friends and family to the institutions themselves. One of these sources of information may be the USNWR rankings. Given the popularity of the rankings as measured by their public consumption (Freedman 2007; U.S. Newes and World Report 2008), it is likely that many students in the process of obtaining information about colleges use the rankings as one of several sources of information.

Even potential students who do not directly use the rankings as a source of information regarding colleges and universities could be affected by the rankings in the search stage. As noted by Bowman and Bastedo (2009), potential students may internalize the college and university rankings either consciously or subconsciously. Given the pervasiveness of the USNWR rankings in American higher education, even students who do not directly reference these publications in their college searches may be indirectly influenced by them through 
institutional advertising, social media outlets, and word of mouth. Each of these factors suggests that institutional rankings may serve as an important resource as students seek information on institutions of higher education.

As students enter the choice stage of the Hossler and Gallagher (1987) model, institutional rankings may begin to play an even bigger role in college decision making. In the choice stage, students focus the search for information on colleges and universities to a short list of preferred institutions, apply to these institutions, and ultimately choose which one to attend. Because many students and parents place great importance on attending high-quality colleges and universities because of the status-attainment advantages these institutions provide (Stevens 2009), perceived institutional quality has historically been found to play a very important role in the college choice process (Cabrera and La Nasa 2000; Matthews and Hadley 1993; McDonough et al. 1997). It could be that students rely on rankings as signals of institutional quality. Without complete information on the true quality of a college or university, potential students are often forced to use salient signals of institutional excellence as proxies for that information (Kotler and Fox 1985). Although empirical research has questioned the link between rankings and educational effectiveness, studies have found that stakeholders use rankings as a signal of overall college or university quality (Bastedo and Bowman 2010; Machung 1998). Therefore, college rankings could lead students in the choice stage to apply to and enroll in higher ranked colleges and universities because of their desire to attend high-quality institutions.

Based on this conceptual framework, it would be hypothesized that within the HBCU sector of the American higher education system, black colleges with better USNWR rankings would have better admissions outcomes such as receiving more applications, having a higher admissions yield, and having a larger freshman class. This hypothesis, however, is somewhat tempered by the findings of Griffith and Rask (2007) and McDonough et al. (1998), which suggest that the student populations typically attracted by HBCUs are less likely to use rankings as an important element in their choice of colleges. This juxtaposition was a motivating factor for this study. The tentative hypothesis of this project was that an institution's ranking within the USNWR "America's Best Black Colleges" would be significantly correlated with HBCU admissions outcomes.

Research Design

Identification Strategies

This study employed methods very similar to those used by Bowman and Bastedo (2009) and Luca and Smith (2013). Data were collected on all HBCUs 
ranked in the first tier of "America's Best Black Colleges" at any time from 2007 to 2011 (app. A lists these schools). ${ }^{1}$ Data from these schools were examined using the following estimation strategy:

$$
\text { Admis Outcomes }_{\mathrm{it}+1}=\alpha \text { Ranking }_{i t}+\sum \beta \text { Covariates }_{i t}+\gamma_{i}+\eta_{t}+\varepsilon_{i t} \text {. }
$$

\section{Dependent Variables}

Four admissions outcomes (Admis Outcomes ${ }_{i t+1}$ ) were used as dependent variables. The first was freshman applications, defined as the total number of firsttime degree-seeking undergraduates (part-time and full-time) who applied to institution $i$ in fall semester $t$. Because the number of applications received is a highly skewed variable, the natural log of the number of applications was used in estimations. The second outcome variable was acceptance rates, defined as the percentage of first-time degree-seeking undergraduate applicants who were admitted to institution $i$ in fall semester $t$. The third outcome examined was admissions yield, which is the percentage of first-time degree-seeking undergraduates accepted to institution $i$ who chose to enroll at that institution in fall semester $t$. The final outcome variable was the seventy-fifth percentile Scholastic Aptitude Test (SAT) score for incoming freshmen at institution $i$ in fall semester $t$. In instances where HBCUs provided American College Testing (ACT) instead of SAT scores, ACT scores were converted to SAT scores using a table provided by the College Board (http://www.act.org/solutions/college -career-readiness/compare-act-sat/). These data on admissions outcomes were gathered primarily from the Integrated Postsecondary Education Dataset (IPEDS). In instances where IPEDS data were not available, university web pages and institutional research offices were consulted.

\section{Independent Variables}

The primary independent variable of interest was college ranking. As noted earlier, schools in the top tier of "America's Best Black Colleges" are ranked numerically, with lower values representing better rankings ( 1 for the top ranked school, 2 for the second ranked school, etc.). In 2007, 37 schools were included in tier 1. From 2008 to 2010, 35 institutions were in tier 1. In 2011, 36 institutions were in tier 1 . Because some schools moved into and out of tier 1 over the 5 years examined in this study, institutions were not assigned a numerical ranking by "America's Best Black Colleges" in some years. For years in which a college or university did not appear in tier 1, it was assigned an overall ranking of 40 . Movement into and out of the top tier was also addressed in 
estimations with a dummy coded variable set to 1 if the institution was in tier 1 and to 0 if the institution was outside tier 1 .

The goal of this study was to explore the independent effect of an HBCU's ranking on admissions outcomes. Because rankings are strongly correlated with several measures of institutional quality, the rankings variable has the potential to be endogenous. To account for this endogeneity, covariates were included in equation 1 to control for changes in the overall quality of a college or university. As previously noted, USNWR determines an HBCU's ranking using a weighted average of its performance on 11 quality dimensions. Ten of these quality dimensions were used as covariates in this study (peer assessment score, freshman retention rate, graduation rate, percentage of classes with fewer than 20 students, percentage of classes with more than 50 students, student/faculty ratio, percentage of faculty that were full-time, twenty-fifth percentile SAT scores of incoming students, acceptance rates, and alumni giving rates). The eleventh quality dimension, the percentage of freshmen in the top $25 \%$ of their high school classes, was dropped because more than half of HBCUs in the sample did not report this information to USNWR. Although these variables may be imperfect measures of quality, they did allow us to control for endogeneity concerns. Endogeneity occurs when the independent variable of interest (in this case, university ranking) is correlated with the error term in a model estimation. By controlling for the factors that determine rankings, we have isolated the portion of the institutional rankings variable independent of changes in institutional quality. Covariate data were obtained from the USNWR ranking publication. In insistences where data were missing on an institution, multiple imputation (MI) where a value for each originally missing data point is predicted using other variables in the model was performed.

Because of the longitudinal nature of the data used in this study, institution and time fixed effects were included in model estimations. The institution fixed effect $\left(\gamma_{i}\right)$ controls for college or university characteristics that may impact institutional admissions outcomes but that are essentially stable from one year to the next, such as control (public vs. private), the location of the school, institutional mission, and general institution size. The time fixed effect $\left(\eta_{t}\right)$ controls for yearly trends that effect all institutions of higher education, such as inflation and national economic conditions. The use of fixed effects means the results of this study should be interpreted as the within-school relationship between a change in college ranking and admissions outcomes (Bowman and Bastedo 2009).

\section{Study Limitations}

Two important limitations must be considered when thinking about the results of this study. The findings have limited generalizability given the use 
of 4-year HBCUs ranked in the top tier of "America's Best Black Colleges." Extrapolating these results to other HBCUs cannot be done. Second, this study relies on self-reported data from colleges and universities to the IPEDS data center and USNWR. In recent years, a number of institutions have admitted to reporting inaccurate data to external agencies in an effort to improve their rankings in national publications or federal reports (Jaschik 2013; Lederman 2009). If HBCUs reported inaccurate information (intentionally or unintentionally) on admissions outcomes or other performance indicators, then the estimates from this study might be biased.

\section{Findings}

Table 1 provides descriptive information on the variables used in model estimations. Examining the dependent variables, we see that freshman applications to HBCUs increased over the 5 years studied. This finding was not unexpected given the recent trend of high school students applying to more colleges and universities (Clinedinst et al. 2011; Hoover 2010). However, as students apply to more institutions, the competition to enroll admitted students increases. This increased competition may explain why HBCU yield rates decreased from 2008 to 2012. In examining the independent variables, we see that HBCUs have been fairly consistent in their performance in USNWR quality indicators. Given that rapid and dynamic institutional change from year to year is not common for most universities (Lombardi et al. 2000), this finding was also somewhat expected.

Table 2 displays the results of the fixed effects regression analyses of the relationship between HBCU rankings and admissions outcomes. A change in institutional ranking, controlling for other measures of institutional quality, did not have a statistically significant relationship on the number of applications received by an $\mathrm{HBCU}(\beta=-0.317, p>.05)$. There was also no significant correlation between being ranked as a tier $1 \mathrm{HBCU}$ and the quantity of freshman applications $(\beta=-10.520, p>.05)$. This result was different from the findings of Bowman and Bastedo (2009) and Luca and Smith (2013), who each found that improved rankings correlated with more applications. So while there is some evidence to suggest that rankings in the top 50 national colleges and universities correlate with applications, we failed to find evidence of this relationship among HBCUs.

We also failed to find a statistically significant relationship between HBCU rankings and freshman acceptance rates $(\beta=0.0002, p>.05)$. This finding is likely a by-product of the finding for freshman applications (if applications are not increasing, schools cannot afford to be more selective). This result again runs counter to previous research. Each of the previous studies that have looked at the relationship between rankings and admissions outcomes (Bowman and 
TABLE 1

Descriptive Statistics for Variables by Year

\begin{tabular}{|c|c|c|c|c|c|}
\hline Variable Name & 2007 & 2008 & 2009 & 2010 & 2011 \\
\hline \multicolumn{6}{|l|}{ Dependent variables: } \\
\hline Applications $(t+1)$ & $\begin{array}{c}4,739 \\
(2,376)\end{array}$ & $\begin{array}{c}4,945 \\
(2,462)\end{array}$ & $\begin{array}{c}4,923 \\
(2,590)\end{array}$ & $\begin{array}{l}5,216 \\
(2,595)\end{array}$ & $\begin{array}{c}5,668 \\
(2,894)\end{array}$ \\
\hline Acceptance rate $(t+1)(\%)$ & $\begin{array}{c}53 \\
(15)\end{array}$ & $\begin{array}{c}51 \\
(15)\end{array}$ & $\begin{array}{l}51 \\
(15)\end{array}$ & $\begin{array}{l}51 \\
(17)\end{array}$ & $\begin{array}{l}50 \\
(16)\end{array}$ \\
\hline Yield $(t+1)(\%)$ & $\begin{array}{l}37 \\
(14)\end{array}$ & $\begin{array}{l}34 \\
(12)\end{array}$ & $\begin{array}{l}35 \\
(13)\end{array}$ & $\begin{array}{c}32 \\
(13)\end{array}$ & $\begin{array}{l}29 \\
(11)\end{array}$ \\
\hline 75th percentile $\operatorname{SAT}(t+1)$ & $\begin{array}{l}977 \\
(96)\end{array}$ & $\begin{array}{l}963 \\
(89)\end{array}$ & $\begin{array}{l}968 \\
(83)\end{array}$ & $\begin{array}{c}965 \\
(76)\end{array}$ & $\begin{array}{l}959 \\
(81)\end{array}$ \\
\hline \multicolumn{6}{|l|}{ Independent variables: } \\
\hline College ranking & $\begin{array}{l}21 \\
(12)\end{array}$ & $\begin{array}{l}22 \\
(12)\end{array}$ & $\begin{array}{l}22 \\
(12)\end{array}$ & $\begin{array}{l}22 \\
(12)\end{array}$ & $\begin{array}{l}21 \\
(12)\end{array}$ \\
\hline Ranked in tier $1(\%)$ & $\begin{array}{l}83 \\
(37)\end{array}$ & $\begin{array}{l}81 \\
(39)\end{array}$ & $\begin{array}{l}81 \\
(39)\end{array}$ & $\begin{array}{l}81 \\
(39)\end{array}$ & $\begin{array}{l}83 \\
(37)\end{array}$ \\
\hline Peer reputation & $\begin{array}{r}3.53 \\
(.47)\end{array}$ & $\begin{array}{r}3.60 \\
(.44)\end{array}$ & $\begin{array}{c}3.52 \\
(.47)\end{array}$ & $\begin{array}{c}3.52 \\
(.48)\end{array}$ & $\begin{array}{r}3.49 \\
(.45)\end{array}$ \\
\hline Retention rate $(\%)$ & $\begin{array}{l}72 \\
(7)\end{array}$ & $\begin{array}{l}71 \\
(7)\end{array}$ & $\begin{array}{l}70 \\
(8)\end{array}$ & $\begin{array}{l}70 \\
(8)\end{array}$ & $\begin{array}{l}70 \\
(7)\end{array}$ \\
\hline Graduation rate (\%) & $\begin{array}{l}43 \\
(12)\end{array}$ & $\begin{array}{l}43 \\
(11)\end{array}$ & $\begin{array}{l}42 \\
(11)\end{array}$ & $\begin{array}{l}41 \\
(11)\end{array}$ & $\begin{array}{l}40 \\
(11)\end{array}$ \\
\hline$\%$ classes $<20$ students & $\begin{array}{c}50 \\
(12)\end{array}$ & $\begin{array}{c}50 \\
(13)\end{array}$ & $\begin{array}{c}50 \\
(13)\end{array}$ & $\begin{array}{c}49 \\
(12)\end{array}$ & $\begin{array}{c}50 \\
(13)\end{array}$ \\
\hline$\%$ classes $>50$ students & $\begin{array}{c}4.3 \\
(4.5)\end{array}$ & $\begin{array}{r}3.9 \\
(3.5)\end{array}$ & $\begin{array}{r}3.9 \\
(3.7)\end{array}$ & $\begin{array}{c}4.2 \\
(3.7)\end{array}$ & $\begin{array}{c}4 \\
(3.8)\end{array}$ \\
\hline Student/teacher ratio & $\begin{array}{l}16 \\
(4)\end{array}$ & $\begin{array}{l}15 \\
(3)\end{array}$ & $\begin{array}{l}15 \\
(3)\end{array}$ & $\begin{array}{l}15 \\
(3)\end{array}$ & $\begin{array}{c}15 \\
(3)\end{array}$ \\
\hline$\%$ full-time faculty & $\begin{array}{c}88 \\
(6)\end{array}$ & $\begin{array}{l}88 \\
(6)\end{array}$ & $\begin{array}{c}89 \\
(6)\end{array}$ & $\begin{array}{l}90 \\
(6)\end{array}$ & $\begin{array}{c}89 \\
(6)\end{array}$ \\
\hline 25th percentile SAT & $\begin{array}{c}807 \\
(84)\end{array}$ & $\begin{array}{c}811 \\
(81)\end{array}$ & $\begin{array}{c}811 \\
(84)\end{array}$ & $\begin{array}{c}813 \\
(74)\end{array}$ & $\begin{array}{l}805 \\
(57)\end{array}$ \\
\hline Acceptance rate $(\%)$ & $\begin{array}{c}54 \\
(16)\end{array}$ & $\begin{array}{c}51 \\
(17)\end{array}$ & $\begin{array}{c}53 \\
(15)\end{array}$ & $\begin{array}{l}51 \\
(15)\end{array}$ & $\begin{array}{c}51 \\
(14)\end{array}$ \\
\hline Alumni giving (\%) & $\begin{array}{c}12 \\
(10)\end{array}$ & $\begin{array}{c}12 \\
(10)\end{array}$ & $\begin{array}{l}12 \\
(9)\end{array}$ & $\begin{array}{c}12 \\
(10)\end{array}$ & $\begin{array}{c}12 \\
(10)\end{array}$ \\
\hline
\end{tabular}

Note.-Variables' means presented. Standard deviations in parentheses.

Bastedo 2009; Luca and Smith 2013; Meredith 2004; Monks and Ehrenberg 1999) found that schools become more selective as their rankings improve.

Neither admissions yield $(\beta=0.001, p>.05)$ nor incoming student SAT scores $(\beta=0.446, p>$.05) were found to be significantly correlated with HBCU rankings. Although the relationship between an HBCU's tier 1 ranking and admissions yield approached significance $(\beta=-0.047, p=.073)$, the direction of the relationship suggests that yield goes down when a school moves into the

FEBRUARY 2016 
Do College Rankings Matter?

TABLE 2

Beta Coefficients for Fixed Effects Regression Analyses of Relationship between HBCU College Ranking and University Admissions

\begin{tabular}{|c|c|c|c|c|}
\hline & $\begin{array}{l}\text { Log Freshman } \\
\text { Applications }\end{array}$ & $\begin{array}{c}\text { Acceptance } \\
\text { Rate }\end{array}$ & $\begin{array}{l}\text { Admissions } \\
\text { Yield }\end{array}$ & SAT \\
\hline \multirow[t]{2}{*}{ College ranking } & -.317 & .0002 & .001 & .446 \\
\hline & $(.59)$ & $(.00)$ & $(.00)$ & $(.98)$ \\
\hline \multirow[t]{2}{*}{ Ranked in tier 1} & -10.520 & .058 & $-.047^{+}$ & -11.995 \\
\hline & $(9.48)$ & $(.03)$ & $(.03)$ & $(11.97)$ \\
\hline \multirow[t]{2}{*}{ Peer reputation } & 11.250 & -.090 & .041 & 1.167 \\
\hline & $(19.19)$ & $(.11)$ & $(.06)$ & $(27.73)$ \\
\hline \multirow[t]{2}{*}{ Retention rate } & 1.061 & -.005 & .000 & 1.632 \\
\hline & $(.79)$ & $(.00)$ & $(.00)$ & $(1.27)$ \\
\hline \multirow[t]{2}{*}{ Graduation rate } & .308 & -.001 & .001 & -2.100 \\
\hline & $(.76)$ & $(.00)$ & $(.00)$ & $(1.28)$ \\
\hline \multirow[t]{2}{*}{ Student/teacher ratio } & -.103 & .000 & .001 & -.042 \\
\hline & $(.35)$ & $(.00)$ & $(.00)$ & $(.48)$ \\
\hline \multirow[t]{2}{*}{$\%$ classes $>50$ students } & $-1.903^{+}$ & .004 & .002 & -.141 \\
\hline & $(1.08)$ & $(.01)$ & $(.00)$ & $(1.47)$ \\
\hline \multirow[t]{2}{*}{$\%$ classes $<20$ students } & .826 & .000 & -.003 & .049 \\
\hline & $(1.48)$ & $(.01)$ & $(.01)$ & $(1.91)$ \\
\hline \multirow[t]{2}{*}{$\%$ full-time faculty } & $-1.255^{+}$ & $.010 * *$ & -.002 & .467 \\
\hline & $(.70)$ & $(.00)$ & $(.00)$ & $(1.34)$ \\
\hline \multirow[t]{2}{*}{ 25th percentile $\mathrm{SAT}$} & .034 & -.000 & -.000 & -.103 \\
\hline & $(.03)$ & $(.00)$ & $(.00)$ & $(.07)$ \\
\hline \multirow[t]{2}{*}{ Acceptance rate } & -.162 & -.001 & .000 & -.203 \\
\hline & $(.23)$ & $(.00)$ & $(.00)$ & $(.26)$ \\
\hline \multirow[t]{2}{*}{ Alumni giving } & -.844 & .004 & .001 & 1.697 \\
\hline & $(.56)$ & $(.00)$ & $(.00)$ & $(1.02)$ \\
\hline $\mathcal{N}$ (institutions $\times$ year $)$ & 197 & 197 & 197 & 191 \\
\hline Adjusted $R^{2}$ & .867 & .623 & .782 & .874 \\
\hline
\end{tabular}

NOTE.-Unstandardized beta coefficients presented. Robust standard errors in parentheses.

+ Significant at $10 \%$ level.

** Significant at $1 \%$ level.

following year. HBCU rankings, controlling for other factors, failed to predict changes in an institution's admission yield or student quality (as measured by standardized tests).

\section{Discussion and Conclusion}

As rankings have become more popular and institutional administrators have shown greater concern about their places in the rankings, many scholars have

\section{American Journal of Education}


attempted to empirically test student responses to rankings. This research has concentrated almost exclusively on institutions USNWR rated as top 50 national universities or liberal arts colleges. These "elite" institutions, however, serve only a small segment of the college student population. To develop a broader understanding of the impact of college rankings, we must expand our research into other subsets of postsecondary education.

This study takes a first step in creating this broader understanding by exploring the impact of USNWR's "America's Best Black Colleges" rankings on admissions outcomes at HBCUs. "America's Best Black Colleges" was introduced by USNWR in 2007 and has been included in the larger "America's Best Colleges" rankings each year since. Using a research design similar to that of Bowman and Bastedo (2009), Luca and Smith (2013), and Monks and Ehrenberg (1999), this study found no evidence that rankings are correlated with the number of admissions applications received by an $\mathrm{HBCU}$, the acceptance rate of an $\mathrm{HBCU}$, the admissions yield of an $\mathrm{HBCU}$, or the SAT scores of incoming students at an HBCU. Do college rankings matter? The answer with regard to HBCU admissions outcomes appears to be no.

The findings of this study largely run counter to those of previous researchers who have looked at college rankings. One potential explanation for this refers back to the work of Griffith and Rask (2007), who found that students receiving need-based aid and racial minority students were less responsive to rankings than other students. Given that HBCUs typically enroll students from lower socioeconomic backgrounds and that more than $80 \%$ of HBCU students are racial minorities (Gasman 2013), these results may show that the HBCU student population is simply less responsive to rankings as a status indicator. The limited financial means of many HBCU applicants may also prohibit easy access to university rankings publications. This presents an interesting question for future researchers. Is the lack of elasticity between HBCU rankings and admissions outcomes due to indifference to the rankings or the lack of access to the rankings?

The findings of this study could also be explained by the heterogeneity of institutional choices for potential HBCU students. Studies that have found a statistically significant relationship between rankings and admissions outcomes have been focused on institutions that attract high-ability, high-income students. These students are likely applying only to other very selective institutions, meaning that these elite colleges and universities are mostly competing with each other for the same students. Under this circumstance, rankings of top 50 institutions provide students with a comparison of all their most likely postsecondary destinations. This could make rankings a more salient tool for differentiating institutions among the highest ranked schools. Students applying to HBCUs, however, likely have a wider range of ability levels and are applying to a broader set of HBCUs and non-HBCUs. "America's Best Black Colleges," however, only ranks HBCUs. Therefore, the findings from this study may be

FEBRUARY 2016 


\section{Do College Rankings Matter?}

explained by the fact that the rankings did not fully capture the group of schools competing for students considering HBCUs. Unfortunately, given the structure of the USNWR rankings, it is not possible to statistically examine this hypothesis.

As future research explores the validity of these and other potential explanations for our study findings, HBCU administrators should feel less concerned about the effects rankings could have on some aspects of institutional well-being. There appears to be no need for HBCUs to make adjustments in student recruitment strategies due to changes in their rankings. This finding may also discourage HBCUs from engaging in the rankings game, in which institutions attempt to move up the rankings without actually improving institutional quality (Machung 1998; Pérez-Peña and Slotnik 2012). The returns to such a game are minimal at best when it comes to potential students. Whether the HBCU rankings are correlated with other institutional outcomes such as faculty recruitment or grant funding should be addressed in future research.

Much to the chagrin of many, college rankings will likely continue to be prevalent in higher education discourse. As a result, it is important that we continue to better our understanding of the role these rankings play in various areas of postsecondary education. This study found that among HBCUs, finishing higher in the USNWR rankings failed to improve the size or quality of an incoming freshman class. This is a refreshing result for those who question the validity of magazine rankings and are concerned about their influence on student college choice.

\section{Note}

1. Given that only tier 1 HBCUs are ranked ordinally in "America's Best Black Colleges," the sample was limited to tier 1 schools in order to more narrowly examine the ranking-admissions correlation. This limited sampling procedure was used by Bowman and Bastedo (2009), Luca and Smith (2013), and Monks and Ehrenberg (1999) in their studies of college rankings. 
Top Tier HBCUs in USNWR “America's Best Black Colleges” (2007-2011)

\begin{tabular}{ll}
\hline Alabama A\&M University & Kentucky State University \\
Albany State University & Lincoln University \\
Alcorn State University & Mississippi Valley State University \\
Bennett College & Morehouse College \\
Bethune Cookman College & Morgan State University \\
Bluefield State College & Norfolk State University \\
Bowie State University & North Carolina A\&T State University \\
Claflin University & North Carolina Central University \\
Clark Atlanta University & Oakwood College \\
Delaware State University & Prairie View A\&M University \\
Dillard University & South Carolina State University \\
Elizabeth City State University & Southern University \\
Fayetteville State University & Spelman College \\
Fisk University & Stillman College \\
Florida A\&M University & Tougaloo College \\
Fort Valley State University & Tuskegee University \\
Grambling State University & University of Maryland Eastern Shore \\
Hampton University & Virginia State University \\
Howard University & Winston-Salem State University \\
Jackson State University & Xavier University of Louisiana \\
Johnson C. Smith University & \\
\hline
\end{tabular}

\section{References}

Allen, Walter R., and Joseph O. Jewell. 2002. "A Backward Glance Forward: Past, Present and Future Perspectives on Historically Black Colleges and Universities." Review of Higher Education 25:241-61, doi:10.1353/rhe.2002.0007.

Ashley, Dwayne, Juan Williams, and Adrienne Ingrum. 2004. I'll Find a Way or Make One: A Tribute to Historically Black Colleges and Universities. 2nd ed. New York: Amistad.

Bastedo, Michael N., and Nicholas A. Bowman. 2010. "U.S. Newes E World Report College Rankings: Modeling Institutional Effects on Organizational Reputation." American Fournal of Education 116 (2): 163-83.

Bowman, Nicholas A., and Michael N. Bastedo. 2009. "Getting on the Front Page: Organizational Reputation, Status Signals, and the Impact of U.S. Newes and World Report on Student Decisions." Research in Higher Education 50:415-36, doi:10.1007 /s11162-009-9129-8.

Cabrera, Alberto F., and Steven M. La Nasa. 2000. "Understanding the CollegeChoice Process." New Directions for Institutional Research 2000 (107): 5-22.

Chapman, David W. 1981. "A Model of Student College Choice." Zournal of Higher Education 52 (5): 490-505.

Chapman, Randall G. 1986. "Toward a Theory of College Selection: A Model of College Search and Choice Behavior." Advances in Consumer Research 13 (1): 246-50. 


\section{Do College Rankings Matter?}

Clay, Phillip L. 2013. "Historically Black Colleges and Universities Facing the Future: A Fresh Look at Challenges and Opportunities." Working paper, Massachusetts Institute of Technology, Cambridge, MA.

Clinedinst, Melissa E., Sarah F. Hurley, and David A. Hawkins. 2011. State of College Admission. Washington, DC: National Association for College Admission Counseling.

Freedman, Samuel G. 2007. "Putting a Curious Eye on a High School Ranking System." New York Times, March 12, http://www.nytimes.com/2007/12/05/education /05education.html.

Gasman, Marybeth. 2011. "Taking a Close Look at the U.S. Newes Historically Black Colleges and University Rankings." Huffington Post, November 29, http://www.huff ingtonpost.com/marybeth-gasman/historically-black-colleges-us-news-ranking_b 982415.html.

Gasman, Marybeth. 2013. The Changing Face of Historically Black Colleges and Universities. Philadelphia: University of Pennsylvania Center for Minority Serving Institutions.

Gasman, Marybeth. 2014. "Context Matters When Ranking Colleges." The Hill, September 29, http://thehill.com/blogs/pundits-blog/education/219148-context -matters-when-ranking-colleges.

Griffith, Amanda, and Kevin Rask. 2007. "The Influence of the U.S. Newes and World Report Collegiate Rankings on the Matriculation Decision of High-Ability Students: 1995-2004." Economics of Education Review 26 (2): 244-55.

Higher Education Research Institute. 2007. "College Rankings and College Choice: How Important Are College Rankings in Students' College Choice Process?"June 20, http://www.heri.ucla.edu/PDFs/pubs/briefs/brief-081707-CollegeRankings.pdf.

Hoover, Eric. 2010. "Application Inflation: When Is Enough Enough?” Nerw York Times, November 5, http://www.nytimes.com/2010/11/07/education/edlife/07HOOVER -t.html? pagewanted $=$ all.

Hossler, Don, and Karen S. Gallagher. 1987. "Studying Student College Choice: A Three-Phase Model and the Implications for Policymakers." College and University 62 (3): 207-21.

Jackson, Gregory A. 1982. "Public Efficiency and Private Choice in Higher Education." Educational Evaluation and Policv Analvsis 4 (2): 237-47.

Jaschik, Scott. 2013. "U.S. Neres Won't Change Bucknell's Ranking." Inside Higher Ed, February 5, http://www.insidehighered.com/quicktakes/2013/02/05/us-news-wont -change-bucknells-ranking.

Kamara, Margaret. 2007a. "Are U.S. Newes' Rankings Inherently Biased against Black Colleges?" Diverse: Issues in Higher Education, June 27, http://diverseeducation.com /artman/publish/article_7831.shtml.

Kamara, Margaret. 2007b. "New HBCU Rankings Get Mixed Reviews." Diverse: Issues in Higher Education, October 3, http://diverseeducation.com/article/9681/new -hbcu-rankings-get-mixed-reviews.html.

Kotler, Philip, and Karen Fox. 1985. Strategic Marketing for Educational Institutions. Englewood Cliffs, NJ: Prentice Hall.

Lederman, Doug. 2009. "Rankings Rancor at Clemson." Inside Higher Ed, June 4, http://www.insidehighered.com/news/2009/06/04/clemson.

Lee, John Michael, and Samaad Wes Keys. 2013. "Repositioning HBCUs for the Future: Access, Success, Research \& Innovation.” APLU Office of Access and Success Discussion Paper 2013-01, Association of Public and Land-Grant Universities, Washington, DC.

Lipman Hearne. 2009. "Five Great Colleges Want Her. How Will She Decide? A Report on High-Achieving Seniors and the College Decision." Washington, DC: Lipman Hearne.

264 American Journal of Education 
Lombardi, John V., Diane D. Graig, Elizabeth D. Capaldi, and Denise S. Gater. 2000. "The Myth of Number One: Indicators of Research University Performance." Gainesville, FL: Lombardi Program on Measuring University Performance.

Lovett, Bobby L. 2011. America's Historically Black Colleges: A Narrative History, 18372009. Macon, GA: Mercer University Press.

Luca, Michael, and Jonathan Smith. 2013. "Salience in Quality Disclosure: Evidence from the U.S. Newes College Rankings." Zournal of Economics and Management Strategy 22:58-77, doi:10.1111/jems.12003.

Machung, Anne. 1998. "Playing the Rankings Game." Change 30 (4): 12-16.

Matthews, Mabel J., and Thomas Hadley. 1993. "The Relationship between an Institution's Perceived Quality and Students' Application Sets." College and University 68:22-30.

McDonough, Patricia, Anthony Lising Antonio, and James Trent. 1997. "Black Students, Black Colleges: An African American College Choice Model." Journal for a fust and Caring Education 3 (1): 9-36.

McDonough, Patricia, Anthony Lising Antonio, MaryBeth Walpole, and Leonor Xochitl Perez. 1998. "College Rankings: Democratized College Knowledge for Whom?" Research in Higher Education 39 (5): 513-37.

Meredith, Marc. 2004. "Why Do Universities Compete in the Ratings Game? An Empirical Analysis of the Effects of the U.S. Nexes and World Report College Rankings." Research in Higher Education 45 (5): 443-61.

Monks, James, and Ron G. Ehrenberg. 1999. "The Impact of U.S. Newes and World Report College Rankings on Admission Outcomes and Pricing Decisions at Selective Private Institutions.” NBER Working Paper 7227, National Bureau of Economic Research, Cambridge, MA.

Pérez-Peña, Richard, and Daniel E. Slotnik. 2012. "Gaming the College Rankings." New York Times, January 31, http://www.nytimes.com/2012/02/01/education/gaming-the -college-rankings.html?pagewanted $=$ all $\&$ r $=0$.

Pitre, Paul E. 2006. "College Choice: A Study of African American and White Student Aspirations and Perceptions Related to College Attendance." College Student Fournal 40 (3): $562-74$.

Stevens, Mitchell L. 2009. Creating a Class: College Admissions and the Education of Elites. Cambridge, MA: Harvard University Press.

U.S. News and World Report. 2008. "Frequently Asked Questions-Media." May 2, http://www.usnews.com/articles/education/best-graduate-schools/2008/03/26 /frequently-asked-questions-media.html\#5.

U.S. Newes and World Report. 2014. "U.S. Newes \& World Report Online Strategy Leads to Record Growth in 2013," January 22, http://www.usnews.com/info/blogs/press -room/2014/01/22/us-news-online-strategy-leads-to-record-growth-in-2013.

White House Initiative on Historically Black Colleges and Universities. n.d. "What Is an HBCU?" http://www.ed.gov/edblogs/whhbcu/one-hundred-and-five-historically-black -colleges-and-universities/. 